DOI https://doi.org/10.30525/978-9934-588-80-8-2.27

\title{
МОДЕЛЬ ВИКОРИСТАННЯ МОБІЛЬНИХ ОСВІТНІХ СЕРЕДОВИЩ
}

\author{
Соя О. М. \\ кандидат педагогічних наук, \\ старший викладач кафедри математики та інформатики \\ Вінницький державний педагогічний університет \\ імені Михайла Коцююбинського \\ Тютюн Л. А. \\ кандидат педагогічних наук, доцент, \\ дочент кафедри математики та інформатики \\ Вінницький державний педагогічний університет \\ імені Михайла Коцуюбинського \\ Косовець О. П. \\ кандидат педагогічних наук, \\ старший викладач кафедри математики та інформатики \\ Вінницький державний педагогічний університет \\ імені Михайла Кочюбинського \\ м. Вінниця, Украӥна
}

Розвиток цифрових технологій зумовлює удосконалення форм i методів взаємодії учасників освітнього процесу. Особливого значення набувають мобільні технології, у педагогічно-виваженому використанні яких вбачаємо можливості інтеграції мобільних освітніх середовищ у традиційне інформаційно-освітне середовище закладу вищої освіти. Проте мобільність передачі інформації ще не забезпечує передачі знань, культури, мислення, а є лише важливим допоміжним засобом навчання. Гнучкість використання інноваційних методів організації освітнього процесу вимагає правильного відбору змісту навчання відповідно до дидактичних властивостей і можливостей онлайн-середовищ; прогнозу можливого впливу новітніх технологій навчання на характер мислення й поведінки учасників освітнього процесу.

Метою роботи $є$ представлення моделі використання мобільних освітніх середовищ у процесі навчання студентів педагогічних закладів вищої освіти.

Особливість підготовки майбутнього вчителя математики, інформатики та фізики полягає в тому, що сучасний студент, постійно 
перебуваючи в швидкозмінному інформаційному суспільстві, здатний самостійно отримувати інформацію 3 електронних ресурсів. Проте, виникає неабияка необхідність навчити його не лише оперативно шукати потрібну інформацію, а й опрацьовувати, засвоювати та використовувати іiі для кращого розуміння навчального матеріалу 3 математичних дисциплін [1, с. 30].

Схематично модель використання мобільних освітніх середовищ у вивченні дисциплін циклу професійної підготовки здобувачів вищої освіти визначаємо як системне поєднання структурних блоків (цільовий, змістовий, технологічний, результативний), сутність яких характеризує особливості та специфіку організації освітнього процесу, передбачає зважений підхід до формування стійкої мотивації до навчання та вибору форм контрольних заходів та критеріїв оцінювання навчальних досягнень студентів (рис. 1).

Цільовий блок використання мобільних освітніх середовищ базується на:

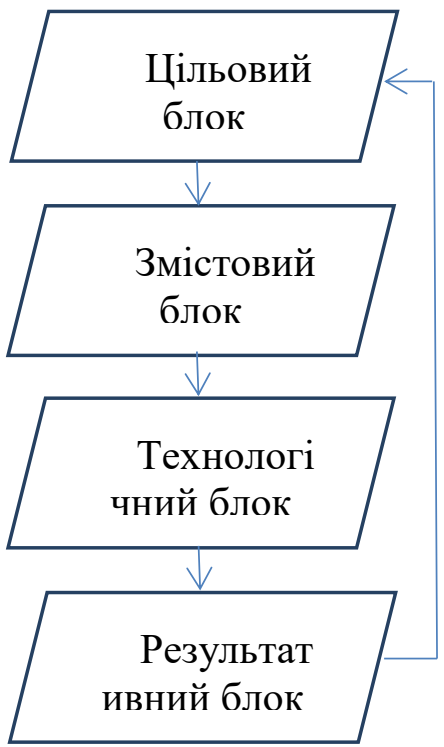

\section{Рис. 1. Модель використання}

- меті та основних завданнях вивчення навчальної дисципліни; 
- формуванні загальних і фахових (спеціальних) компетентностей здобувачів вищої освіти для досягнення програмних результатів навчання 3 кожної освітньої компоненти відповідно до освітньопрофесійної програми підготовки фахівців;

- тріаді цілей навчання (освіта, розвиток, виховання), що випливає 3 загальної дидактики і конкретизується відповідно до конкретних освітніх компонентів.

Змістовий блок містить інформаційний обсяг кожної навчальної дисципліни відповідно до ії місця в освітньо-професійній програмі (кількості кредитів ЄКТС, загального обсягу, співвідношення кількості годин аудиторних занять та самостійної роботи до загальної кількості годин, розподілу кредитів ЄКТС на тиждень за курсами і семестрами, форм контрольних заходів та критеріїв оцінювання навчальних досягнень здобувачів вищої освіти.

Технологічний компонент використання мобільних освітніх середовищ передбачає можливість застосування в освітньому процесі сучасних методів і технологій навчання, необхідність оволодіння студентами відповідними знаннями та уміннями роботи 3 сучасними інформаційними ресурсами:

- уміння поєднувати традиційні й сучасні технології навчання у процесі навчально-пізнавальної діяльності;

- уміння самостійно працювати 3 різноманітними інформаційними джерелами, зокрема 3 електронними підручниками, посібниками, довідниками, конспектами (розуміти прочитане, систематизувати матеріал, конспектувати, роботи тези, опорні схеми, таблиці, тощо) та Інтернет-ресурсами (пошук, сприйняття, розуміння, відбір, аналіз, опрацювання, організація і представлення, збереження і передавання інформаціі);

- знання технологій роботи з програмним забезпеченням загального призначення (сучасними пакетами математичних програм, текстовими $\mathrm{i}$ графічними редакторами, електронними таблицями для опрацювання числових даних, програмами створення презентацій, базами даних, електронними підручниками і посібниками);

- знання алгоритмів, методів, прийомів і способів ефективного розв'язування задач за допомогою комп'ютера та мобільних за стосунків (володіння навичками алгоритмізації, усвідомлення мобільних освітніх середовищ як універсального виконавця задач);

- уміння користуватися електронними засобами зв'язку (знання способів передавання інформації на відстані, використання електронної пошти, впровадження технологій віддаленого спілкування й навчання, функціонування комп’ютерних мереж тощо). 
В умовах змішаного й дистанційного навчання значимість мобільних освітніх середовищ значно зростає. Основна причина цього - можливості, які вони надають: організація взаємодії студентів між собою,з викладачами, адміністрацією; спільна робота учасників освітнього процесу над завданнями аудиторно та в поза аудиторний час; миттєвий обмін інформацією тощо.

Науково-технічний прогрес істотно сприяе розширенню та вдосконаленню використання мобільних освітніх середовищ, оскільки сучасні портативні девайзи стають легшими, дешевшими, з більшою роздільною здатністю екрана, більшим ресурсом акумулятора, підтримкою різного покоління передачі даних (3G, 4G, 5G Інтернету) та можливістю встановлення різноманітного програмного забезпечення. Тому мобільне навчання, як галузь, що стрімко розвивається, розглядається деякими науковцями як навчання майбутнього, що дозволяє незалежно від місця перебування, в комфортних умовах опрацьовувати новий матеріал, працювати над закріпленням нових знань, самостійно перевіряти програмні результати навчання тощо.

Можливості й особливості використання сучасних цифрових технологій, зокрема вільного програмного забезпечення, різнобічно досліджуємо, аналізуємо та порівнюємо. А також активно використовуємо їх під час упровадження змішаної та дистанційної форм організації освітнього процесу.

Модель використання мобільних освітніх середовищ також забезпечує реалізацію принципів універсального дизайну у процесі навчання студентів інклюзивних груп педагогічних закладів вищої освіти [2, с. 15].

Наразі знайшли своє застосування і добре себе зарекомендували такі мобільні програмні засоби й сервіси:

- Google-сервіси (GoogleClassroom, GoogleDrive, Gmail, GoogleMeet, GoogleSites, YouTube та інші) - для комунікації та спільної роботи 3 документами;

- Skype, Viber, Zoom, Telegram, WhatsApp - засоби інтернеттелефонії;

- GeoGebra, Photomath, MalMath, FreeGraCalc, Desmos, QuckGraph+, GeometryPad, TriangleSolve, iCrosss, ToolKitPro, SmartMeasure тощо мобільні додатки математичного спрямування;

- Matific, GIOS, Learning.ua, Quick Brain, Fractionsforkids, ua.OnlineMSchool.com, GeometryPad, ICrosss, Euclidea, Піфагорія, Король математики тощо - математичні ресурси для змішаного навчання шкільного курсу математики. 
Таким чином, реалізація технологічного блоку передбачає забезпечення продуктивного зворотного зв'язку між науково-педагогічними працівниками та здобувачами вищої освіти у процесі навчання; ефективну комунікацію між викладачем і студентами; конструктивну реакцію викладача на освітні запити та потреби студентів.

Результативний блок містить форми і методи онлайн-оцінювання, що забезпечують валідність оцінювання успішності студентів та встановлення факту досягнення результатів навчання; критерії оцінювання, що описують те, що здобувач освіти здатний виконувати для демонстрації здобутого результату навчання. Форми (методи) та критерії оцінювання узгоджуються з результатами навчання і з видами навчальної діяльності, що реалізовувалися в процесі навчання. Форми проведення контрольних заходів у межах навчальних дисциплін обираються викладачами залежно від особливостей вивчення освітніх компонентів та прогнозованих програмних результатів навчання.

Отже, створення й використання мобільних освітніх середовищ у процесі навчання студентів педагогічних закладів вищої освіти вимагає правильного відбору змісту навчання відповідно до дидактичних властивостей і можливостей засобів цифрових технологій навчання; прогнозу можливого їх впливу на характер мислення і поведінки учасників освітнього процесу тощо.

\section{Література:}

1. Semenets D. A., Soia O. M., Tyutyun L. A. Functioning of virtual educational environments in higher education in context of continuous education. Progressive Science Journal. 2019. № 1. P. 28-32.

2. Kosovets O. P. Principles of a universal design in a methodical system of teaching computer science students in inclusive groups. Scientific Vector of the Balkans. 2020. T. 4. No 2(8). P. 14-17. 